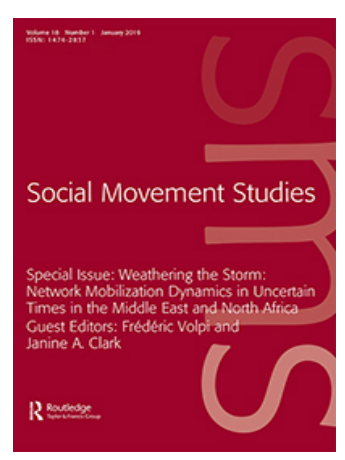

Social Movement Studies

\title{
Local mobilisations and the formation of environmental networks in a democratizing Tunisia
}

\section{Chiara Loschi}

To cite this article: Chiara Loschi (2019) Local mobilisations and the formation of environmental networks in a democratizing Tunisia, Social Movement Studies, 18:1, 93-112, DOI: 10.1080/14742837.2018.1540974

To link to this article: https://doi.org/10.1080/14742837.2018.1540974

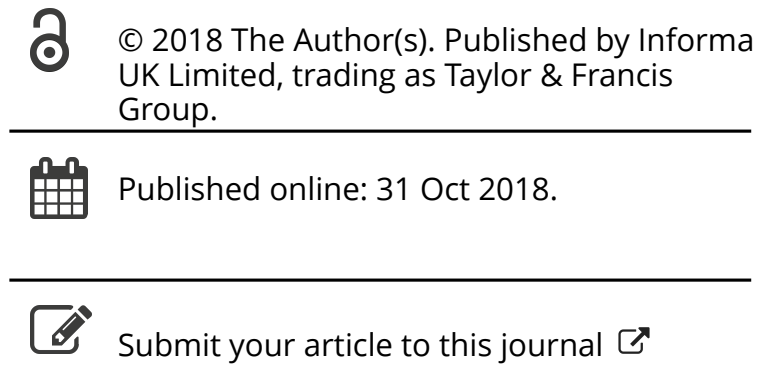

щ Article views: 295

View Crossmark data ¿

Citing articles: 1 View citing articles ¿ 


\title{
Local mobilisations and the formation of environmental networks in a democratizing Tunisia
}

\author{
Chiara Loschi ii \\ Institute for European Integration Research, University of Vienna, Vienna, Austria
}

\begin{abstract}
This study examines the environmental protests that occurred in Tunisia after the 2011 uprisings. It analyses the factors underpinning the rise of the environmental networks during the period of transition (2011-2014). It details the mobilising strategies that were crucial for the networks' growth or survival during this period of institutional instability. The study shows how networks leaders were able to bring together social and political actors from different backgrounds and ideological orientations. It is argued that the ability of networks to develop new distinctive collective identities was crucial for network sustainability. Those networks and actors who did not develop new clearly defined environmental identities and continued to rely importantly on pre-existing (authoritarian) structures and practices were more negatively impacted by ideological cleavages and political calculations. Empirically, the contribution builds on interviews and observations, as well as documents collected from Tunisian municipalities between 2013 and 2015. Conceptually, the research proposes a bottom-up perspective that highlights the interplay between micro- and macrodynamics and strategies during a political transition. The analysis details the actors' capacity to build alliances via interpersonal relations at the micro level, and their strategies to engage with institutional actors and processes.
\end{abstract}

\section{ARTICLE HISTORY}

Received 15 January 2018

Accepted 11 October 2018

\section{KEYWORDS}

Environmental movements; Tunisia; social networks; waste management; local governance

One of the most visible effects of the 2011 uprising in Tunisia were mountains of uncollected garbage, not only in lower income neighbourhoods but also in well-off districts and cities throughout the country. The scenario became all too familiar to both citizens and tourists visiting the country on holiday. With the downfall of the authoritarian regime, solid waste management entered a phase of instability, triggering a number of protest mobilisations in response. Organised in networks, activists sought to address both generic environmental challenges in the country and the problems of solid waste management at the national, but also specifically at their local, level. Some of these networks evolved and became entrenched over time as they organised these agendas and developed a specific associative identity, others disappeared.

The present study analyses the factors that most impacted the environmental networks during the period of transition, starting from January 2011 to January 2015. It details the mobilising strategies that underpinned the networks' survival during this 
period of institutional instability. The study shows how network leaders were able to bring together social and political actors from different backgrounds and ideological orientations. It outlines how leaders cultivated or discouraged specific types of interactions within the networks and shows, in the case of resilient networks, which approaches and identities were most effective in shaping mobilizations and collective action during the transition period. The argument is that the ability of networks to develop new, distinctive collective identities was crucial for network sustainability. This process enabled the strengthening of social ties and the displacement of practices inherited from authoritarian modes of mobilisation, for instance to tightly restrict access to information about the environment and pollution. Those actors who did not develop new, clearly defined environmental identities and continued to largely rely on pre-existing structures and practices were more negatively impacted by ideological cleavages and political calculations. Networks with a clear identity and agenda were also better able to connect with different types of localized activism and in so doing were able to strengthen the network's structure.

Empirically, the study compares two environmental social networks and their subnetworks that emerged and evolved between 2013 to 2015 in Tunis, the capital of Tunisia, and Djerba, an island in southern Tunisia. The investigation builds upon different research material collected in Tunisia from 2013 to 2015: a) a total amount of 26 formal interviews, sometimes in multiple rounds, conducted in Tunis and its neighbourhoods, and in Djerba (areas of Homt-Souk and Midoun) with activists, workers, citizens and local representatives of municipalities (21), with international donors (2) and Tunisian national authorities (3); c) participant observation of 7 rallies in cities and landfills as well as meetings and press conferences conducted by these associations, during which informal interviews were conducted. The research abides by ethics of confidentiality and informed consent, and granted anonymity for participants who asked it.

The contribution analyses these environmental networks not as part of a global environmental movement, but rather as an example of a (relatively) free form of social mobilisation after the fall of the authoritarian system. The two environmental networks are representative of mobilisations in different sectors of society that were highly controlled by the regime before the 2011 revolution. Following the regime's fall, actors were able to mobilise for the first time without facing harsh repression. Still, during the transition period, they faced the legacy of the old institutional system and the legacy practices of authoritarian governance. Activists were able to test formal and informal strategies of collective action whilst political and institutional changes were still ongoing. Although environmental protests were common throughout the country at that time, the cases of Tunis and Djerba are particularly interesting due to the endurance and intensity of these mobilisations, which illustrated different forms of collective action and of interactions with national and local institutions.

The focus of the case studies is on the interplay between micro- and macrodynamics and strategies. For the networks, the analysis details the actors' capacity to build alliances via interpersonal relations at the micro level, and their strategies in engaging with significant institutional actors and processes. The first section of the contribution focuses on the authoritarian control of solid waste management prior to 2011, which paved the way for the emergence of the environmental problems and networks which this research analyses. The second section focuses on how the first 
wave of activists constructed networks and alliances to address these environmental issues, and in so doing created a collective identity and agenda. In the third section, the contribution examines how the networks evolved and how far the leadership was able to take advantage of the transitional instability to ensure the durability of their networks.

\section{Social networks and mobilisation in post-authoritarian contexts}

Mobilisation and activism in the Middle East/North Africa (MENA) region have historically been investigated through the prism of informal networks and micro-scale analysis (Beinin \& Vairel, 2011). In this context, the study of social activism in the MENA region has emphasized the presence and political implications of urban mobilizations, squatters' movements and Islamic activism under authoritarian rule (Bayat, 1997; Huber \& Kamel 2015; Singerman, 1995; Wiktorowicz 2004). The 2011 Arab uprisings brought to the fore the role of unorganised actors over traditional collective actors (political parties, collective movements) with a special focus on local level of mobilisation (Allal \& Bennafla, 2011; Bayat, 2010). Research has shown that local scenes reveal the dynamics of proximity between state and citizens and show how states are locally 'continuously constructed, deconstructed, and reconstructed' by citizens (Hoffmann, Bouziane, \& Harders, 2013, p. 7). In this context, an approach based on networks was useful in order to investigate the 'dense, overlapping social networks' that emerged during the 2011 protests and their aftermath (Leenders \& Heydemann, 2012, p. 146). In particular, the focus on networks allows for a deeper understanding of interpersonal relations among activists, and their agency and strategic choices regarding the building of mobilizations.

During the following analysis networks are considered to be the outcome of interactions that entail a certain degree of contingency and fluidity, and which cause gradual changes to the social ties that structure the relationships between the members (Diani \& Mische, 2015). In a similar manner to the work of Jasper (2011), the following investigation will focus on the interactions among individuals or groups who share a sense of identity, and goals and who cooperate in the same arena.

At a micro level analysis, interpersonal ties are a tool of mobilising actors to encourage the extension of an invitation to participate and to ease the uncertainty of mobilisation (McAdam \& Paulsen, 1993). In a repressive context, Singerman's (2004) investigation of Islamist activism illustrated how, at a network level, processes of identity construction constituted a more important factor of activism than actions undertaken in public. Focusing on networks enables us to better see the relationships between mobilising actors 'below the official stories and representations that movements and their activists make' (Krinsky \& Crossley, 2014, p. 1). In repressive political contexts, clandestine organisations rely upon strong social ties and mutual trust that create a basis for mobilisation by providing actors a conduit of information, allowing them to build key alliances and challenge the state's monopoly on reigning ideologies (Alhamad, 2008, p. 43). In this context, the recruitment of new members depends upon interpersonal ties to the extent that interpersonal contacts dominate the actors' strategies and the networks' processes (Passy, 2003). 
Extending the network approach to the investigation of Arab politics after the 2011 upheavals means to look in the details of interpersonal ties and strategic interactions between actors and networks; and to question the causal primacy of structural processes and political opportunities for collective action. To look at mobilizations during transition and during political instability means to acknowledge that after an authoritarian system falls apart, subsequent mobilizations can contain both elements of innovation and authoritarian mechanisms embraced by actors. The author's analysis of the characteristics of environmental social networks starts from the position that 'prior social ties operate as a basis for movement recruitment and that established social settings are the locus of movement emergence' (Diani, 2003, p. 3). The account of social ties within the two case studies presented here is strictly connected to the investigation of the creation and role of network's collective identities. It focuses on the identification of 'the circumstances in which different relations between interest and identity, strategy and identity, and politics and identity operate, circumstances that include cultural processes as well as structural ones' (Polletta \& Jasper, 2001, p. 285). In particular, the following investigation elucidates the strategic choices made by network leaders in times of political transition.

A focus on social networks during a transition allows for the understanding of both individual agency and institutional constraints, so environmental networks can 'serve as a window onto changing state-society relations' (Sowers, 2013, p. 3). With some remarkable exceptions (Florin, 2012; 2015; Deboulet \& Florin, 2014; Furniss, 2016; Sowers, 2013), scholarship on political processes in the MENA region has paid little attention to environmental politics and social networks. In many ways, the 2011 uprisings reinforced the links between environmental questions, authoritarian governance and mismanagement. In Beirut in 2015, networks of activists mobilised together around the Twitter hashtag \#YouStink (طل عت_ريحتكم) to address the environmental crisis created by the closure of a central landfill which left mountains of garbage piled up the streets of the capital. (AbuRish, 2015; Geha, Forthcoming; Yahia, 2015). The protesters claimed that the environmental crisis was the outcome of the sectarian system's inability to address deteriorating service provision as the political elites engaged in backroom negotiations 'over which company should be awarded the lucrative garbage collection contracts' (Yahia, 2015).

In the case of Tunisia, many of the environmental protests linked to the 2011 uprising have their roots in older forms of mobilisation. For instance, in the oases of Tozeur and Gabès in southern Tunisia, local environmental protests build on a long history of mobilisations against industrial projects by energy corporations and the petrochemical industry, the protests focused on environmental impact, poor labour conditions, and the informalization of local economies and draining of small farm and peasant communities (Ayeb, 2012; Carpentier \& Gana, 2017; Feltrin, 2017). Moreover, in the suburbs of all the larger Tunisian cities, rapid urbanisation and uncontrolled industrialization have had negative impacts on living conditions and service provision (Signoles, 1999). These trends laid the foundation for the dynamics of contention in local politics that came to the fore at the municipal level during the 2011 uprisings (Volpi, Merone, \& Loschi, 2016). After 2011, social mobilization in environmental networks could exploit the new infrastructure provided by the new or liberalized media, and the attention paid by international organisations and donors towards the Tunisian transition. 
Environmental activism in Tunisia grew strong during the transitional phase, which in this paper refers to the period between the fall of Ben Ali in early 2011 and the second parliamentary elections at the end of 2014. This was a time when the country's new formal institutions were trying to consolidate themselves and mobilisations varied greatly according to the opportunities present in this new political landscape. It was also one the most unstable moments in modern Tunisian history with regard to the legitimacy of the political elites, state institutions and democratic procedures. For a country that had been characterized by stable authoritarianism since independence in 1956, this episode of political transformation brought with it a wave of uncertainty. Established social and political actors had to reposition themselves and reinvent their identity to become in tune with the changes brought about by the revolution. Yet at the time it was unclear for all those involved whether the 2011 uprising would bring real institutional change or whether it would entrench some form of continuity with the old regime. This continuity was linked to the alleged presence of a Tunisian 'deep state' in the Nidaa Tounes party and in the bureaucracy (Gelvin, 2015). After the regime fell, senior figures from the former ruling party, the Democratic Constitutional Rally (Rassemblement Constitutionnel Démocratique (RCD)), joined Nidaa Tounes, a new party created after 2011 (Preysing, 2016). However, new actors emerged across the social and political spectrum, while older, previously outlawed organisations were able to participate in this ongoing wave of mobilisation (AntonakisNashif, 2016; Fortier, 2015; Gray, 2012).

The Tunisian political transition provides the structural background against which this paper analyses the rise of environmental networks, and the new relations that they establish between citizens and state authorities and between themselves, as they address and politicize environmental issues. From this standpoint, the identity and role of the networks are 'social constructions constituted in large part by the shared understandings of participants' (Sowers, 2013, p. 13). New political meanings emerge when participants activate discourses and practices related to the environment; when they choose to engage with, or to intentionally elude, public and private actors, how they craft their relations with central and peripheral communities, national and local institutions; when they seek to leverage ambiguities in legal authority, when they choose among constituencies to mobilized. By analysing how environmental initiatives and networks emerge, fail or are strengthened, this paper identifies the factors that most heavily influence variations in outcomes.

While there are several works on the topic of how networks originate, how social ties represent sources of recruitment and fertile ground for the emergence of movements, and what form the patterns of relations among actors take, little attention is paid towards the implication of interactions by the activists and their collective identities in terms of the networks' survival in the long run. Furthermore, discussions of collective identities in social movements typically analyse how individuals created these identities, and how they transformed them into collective actions, with little room given to understanding these collective identities in light of longer-term dynamics. This research aims to fill this knowledge gap by discussing the role of collective identities from a longer-term perspective. The identities emerging in the chosen case studies are the result of different strategies, and they lead to different outcomes: the network's survival, or its end. This research helps to contribute to the 
literature by elucidating variation in outcomes through analysis of the collective identities' role in different stages of mobilization. To this aim, this work will study the tactics that leaders employed vis-à-vis different levels of state authorities, discourses about authority and expertise, and engagement with different stakeholders (including other networks) related to environmental issues.

\section{Ben ali's solid waste management and protest mobilisations}

During the 2011 riots, protesters in Tunisia's cities set trucks carrying waste on fire and destroyed municipal service delivery equipment. Given that waste collection was the most important service with which municipalities were tasked under the former regime, environmental activism emerged in the local and municipal arena. While municipal control of waste collection dates back to the 1990s when international actors supported structural reforms that promoted decentralisation, the governance of the service was still firmly controlled by national institutions. In the following section, this paper analyses how the governance practices and institutional structure of solid waste management in Ben Ali's regime influenced the 2011 riots and provided the context in which environmental networks emerged in 2011 and after.

Prior to 2011, solid waste management was part of the regime's 'authoritarian upgrading' programme deployed via the structural adjustment programmes (SAPs) that began to be introduced in Tunisia at the start of 1986 (Hibou, 2006). The International Monetary Fund and the World Bank sought to adjust the Tunisian state's role in the national political economy by supporting new public management-like reforms, such as decentralisation, through the outsourcing of service delivery, such as rubbish collection, and the enhancement civil society participation. ${ }^{1}$ Yet, while Tunisian municipalities embodied a decentralized administration, one that was formally elected, their political and administrative decision-making was formally and informally overseen by the regime through deconcentrated, ${ }^{2}$ unelected administrative tiers. The Ben Ali regime reinforced control over local politics in multiple ways. Municipalities were formally elected bodies, but electoral laws for municipal councils specified measures that assigned a form of proportional representation to parties. Ben Ali used the administration and the ruling party's structures to control the local candidates and party lists in order to reduce any threat to the dominance of the ruling party (Gobe \& Chouikha, 2000; Sadiki, 2002). ${ }^{3}$ Local governance was built around deconcentrated administrative tiers and especially the 'umda (district chief) (Hibou, 2006; King, 2003). This key local actor was 'at the lowest level of an extensive hierarchical administrative structure that went all the way up to the Ministry of the Interior' and its Directorates of Local Authorities (Volpi, 2013, p. 369). Within this structure, regional governors were tasked with a priori and a posteriori approval of any decisions and budgetary amendments made by municipalities (Tizaoui, 2009).

Additional top-down control was implemented at the institutional level in 2005, when the Ben Ali regime created the National Agency for Solid Waste Management (Agence Nationale de Gestion des Déchets (ANGeD)). This agency was responsible for the entire waste management cycle and became the de jure owner of dumps and solid waste transferring centres, which it then outsourced to private businesses close to the regime. The largest dump in Tunisia is the Borj Chekir landfill, created in 2000 and 
directly managed by ANGeD; from 2009 to 2011 it was overseen by the French company Pizzorno. ANGeD also controlled municipal actors by bypassing the Directorate of Local Authorities, the administrative department within the Ministry of Interior accountable for decentralization and the monitoring of municipal affairs, and directly providing external funds to some municipalities which were showcased as examples of good governance by the regime. By way of contrast, many lower-income municipalities were unable to access these funds and had to cope with garbage problems by themselves or, worse, had to cope with those of their neighbours. For instance, municipal actors in Ettadhamen, a popular neighbourhood in Tunis' suburbs, noted that their vacant fields and roads were used as open dumps when 'Ben Ali's regime needed to clean the roads in Tunis and in well-off cities fast'. ${ }^{4}$

In this context, citizens held both national administrations and municipalities accountable for service delivery but had little room to express dissent. As a resident based close to Borj Chekir described:

We wrote several letters to ANGeD and the Health Minister. Before 2011, sometimes we didn't get a response, and sometimes they sent the police. They intimidated us to stop us from complaining and told us that everything was up to standard. But we never knew anything. We just smelled this disgusting air and got sick. ${ }^{5}$

During the 2011 upheavals, early protesters organised quick, opportunistic actions against the national agencies and municipalities in the Tunis area, the protests first started in the Borj Chekir landfill and in Ettadhamen-Mnihila. There, rioters set depots and rubbish collection equipment alight; a pattern that would later be duplicated in many other cities. In Borj Chekir, landfill workers occupied their own landfill with the aim of ending the stockpiling of waste that not only smelled bad, but was causing the local population to become ill. At the same time, citizens living in the nearby village of el-Attar took to the streets and organised sit-ins, thereby closing off access to the site. ${ }^{6}$ Following the upheavals, most local authorities ceased to function and the country's town councils were replaced by 'special delegations' (délégations spéciales; in Arabic, niyabat khoususiyya,) appointed by decree of the Interior Minister (Volpi et al., 2016). ${ }^{7}$ At the national level, ANGeD was heavily discredited as competition rules regarding calls for tenders were not respected and it lacked adequate means to address technical failures and systemic inefficiencies. ${ }^{8}$

Many of the mobilisations in early 2011 embraced the environmental agenda as a tool of resistance against the political system. After the first democratic parliamentary elections of October 2011 and the victory of the Ennahda party, a conservative, Islamist party, many local mobilisations continued targeting national authorities. The various opposing forces commonly recycled established ideological divisions (for example between leftist, secularist and Islamist actors) and, to some extent, replicated older patterns of political participation. For example, the Tunisian General Labour Union (Union Générale Tunisienne du Travail (UGTT)) organised strikes from 2011 to 2014 to reach a national agreement whereby around 12,000 temporary road sweepers and dump site workers gained open-ended employment. These workers, most of whom were employed by municipalities and governorates on temporary contracts, were among the first to take to the streets during the uprising. ${ }^{9}$ However, although the UGTT contributed to the emergence of structured mobilization on environmental issues, it 
wasn't acting in support of a clear environmental agenda. It rather sought to strenghten its national role as the guarantor of social justice as well as buttress its image as a leading actor within the push for political change in relation to the transitional authorities (Omri, 2013). Nevertheless, it indirectly fostered the diffusion of environmental mobilization, as the ongoing mobilisations exacerbated the environmental situation in the cities and urban belts and increased discontent among citizens, leading to new cycles of protests.

\section{The strategies of the new environmental networks during political transition}

Starting in 2012, a number of environmental networks emerged to address solid waste management problems while distancing themselves from the strategies and ideological positions of the national political actors. This trend would be reinforced after the ratification of the Tunisian Constitution in early 2014, as the new institutional setting created conditions that facilitated the creation of environmental networks. Formally, the 2014 Constitution included articles referring to environmental protection and the promotion of sustainable development (Ferchichi, 2014). However, at the institutional level, the Ministry of the Environment was merged with the Ministry of Equipment, so that the Minister of Environment post no longer existed and the under-secretary of the Ministry of Equipment fulfilled the role; a situation that gave rise to further environmental protests. This section investigates how mobilising actors sought to capitalise on interpersonal ties and political opportunities to transform local protests into an organised environmental movement. It examines the different strategies that leaders chose to build their network, and their impact on the networks' durability

In the early years of transition, before the constitution was approved, several informal mobilisations emerged and created sporadic riots and sit in for the environmental situation. One of the most successful networks that emerged in the capital during the transition was created by Morched Garbouj, a Tunisian engineer, in late 2011. Together with his friends and work colleagues, he created an NGO named SOS BIAA ('biaa' means 'environment' in Arabic). At the same time, Karim Abdelwahed, an employee of the Ministry of Health and an acquaintance of Garbouj, created the Tunisian Association for Health Promotion (Association Tunisienne pour la Promotion de la Santé (ATPS)). After 2011, freedom of contestation vis-à-vis dismissed regime allowed both SOS BIAA and the ATPS arguing that solid waste management had been severely lacking under the Ben Ali's regime, and that 2011 upheavals ended authorities' control of information on long-term pollution of air, water and ground around dump sites, in cities and on the coast, with important implication of public health. These two NGOs sought to act as watchdogs, monitoring the actions of national institutions, and trying to mobilize public opinion to help citizens 'step out of the shadows $^{10}$ and share any information available on pollution and health issues. These two new associations built their inner structures around personal ties and reinforced this structure by including like-minded individuals. Garbouj sought to introduce Tunisian civil society to the practices of advocacy campaigns as undertaken in the Western world and in transnational environmental organisations. With Garbouj coordinating, SOS BIAA appeared to be the most proactive group in creating sit-in and 
awareness campaigns in industrial sites, cement plants, and domestic and industrial waste dumps, while reinforcing its image on social networks.

Since the inception of their activities, one of the most important area of mobilisation for the networking associations was the Borj Chekir landfill. The oldest and biggest dump of Tunisia could attract attention from national and international audience while being close to the capital. The associations backed the inhabitants' claims that the landfill was illegally spreading onto the village's land ${ }^{11}-$ a situation that was deemed to be at the root of the many cancers, rashes, skin allergies and respiratory problems suffered by the population. The network formulated complains against the ANGeD and other national institutions in charge of environmental issues and helped the inhabitants of Borj Chekir to present their claims to the Health Ministry, ${ }^{12}$ claims that were presented during mediation arranged by ATPS president Abdelwahed, although these delivered very limited outcomes.

This profile of a watchdog and association supporting citizens' claims against the government is something unprecedented for Tunisia. Moreover, Garbouj's choice to rule out any political positioning and affiliation proved to be highly appreciated both by activists and international donors. With the aim to enlarge the network sphere of action and structure, Garbouj also endeavoured to increase the organisation's role as an environmental policy advisor on water, ground, air pollution. Both SOS BIAA and ATPS strengthened relations with individual scientists from private companies and reinforced the expert approach to insist on the technical evaluation of the dangers of uncollected rubbish, the ineffective management of waste transport and stocking. Laboratory tests' results on ground and water pollution were discussed during conferences broadcasted on Facebook and Youtube pages, which served as a tactic to better market the role of the network and reinforce inner connections with other local actors. Thanks to his proactive approach to finding partners and visibility, in 2014 Garbouj started to gain financial support from international donors, such as the German Friedrich Ebert Foundation, to sponsor such conferences and divulgation activities gathering protesters, stakeholders and public institutions. ${ }^{13}$

Thanks to these actions, Garbouj, the leader of both the NGO and the network, strengthened the network's structure initially based upon personal ties and connections with engineers and researchers, and reinforced the network's identity as environmental advocate, backing citizens' claims against the government, and as the provider of factual information on pollution, while at the same time dismissing any manifest partisan political affiliation.

The second important case covered in this paper occurs on the island of Djerba. The island's main environmental issue is related to a landfill located in Guellala, the southeast part of the island far from the 5-star hotels which are the main attraction for the island, and managed by a private firm, Segor. The landfill had been temporarily closed in 2011 due to local complains similar to those of residents near the Borj Chekir landfill in Tunis. The landfill was then reopened on a temporary basis while the three temporary municipal councils of the island ${ }^{14}$ negotiated with national institutions regarding the construction of a new composting plant. This process did not produce tangible results. Indeed, in 2012 and 2013, violent riots highlighted serious conflicts between citizens, local representatives of the Troika government and local branches of the UGTT, ${ }^{15}$ and sporadic riots started occurring again in May 2014, when local residents 
near the Guellala dump blocked the access to the site, claiming that the dump still produced foul smells that reached houses and schools. Following these riots, the temporary municipal council of Homt-Souk chose to resign in June 2014 rather than face a potentially long-term conflict with the local population. As a consequence of the council's resignation, all decision-making powers returned to the governor and the provincial representatives (delegates). ${ }^{16}$ In other words, environmental issue went back under the control of national authorities.

At this point, civil society organisation representatives entered the scene. The Association pour la Sauvegarde de l'̂le de Djerba (ASSIDJE), a historical association linked to protection of the island's environment, set up a 'crisis cell' in order to mediate between citizens and national institutions. The ASSIDJE had been founded in 1976 and had been one of the few civil society organisations that the Ben Ali regime tolerated and which he would refer to in order to access international programs dealing with seaside and marine protection, nurturing the uniqueness and legitimacy of that association on the island. The crisis cell was set up in 2014 and included local representatives of the UGTT, the UTICA, supporters of Ennahda and of the Congrès pour la République (CPR), as well as the representatives of important professional networks, including the Hotels Confederation. ${ }^{17}$ Their aim was to 'put the pieces together' and deliver a solution for the national authorities to implement. ${ }^{18}$ Moreover, Naceur Boubabid, the president of ASSIDJE at that time, presented the crisis cell as a horizontal network of organisations with no specific leader.

The first and only public event the crisis cell organised was a general strike on 30 September 2014 with the aim to focus the attention of local and national authorities and public opinion on the rubbish crisis. ASSIDJE made its main resources available, a network of volunteers who coordinated the preparatory meetings and press releases about the strike action, and its own local legitimacy grounded in its long-term presence and its history of environmental activism on the island. The day of the mobilization, the staff at the island's airport, hotels, schools and ferryboats, went on strike; the news soon reached the national mass media, including both public and private TV and radio channels, both in French and Arabic.

The ASSIDJE-inspired general strike allowed, for the first time since the beginning of the crisis on the island, non-violent activism and the inclusion of actors from different political backgrounds, as well as actors who defined themselves as apolitical. ${ }^{19}$ There had been continuous strikes following the closing of Guellala, but the ASSIDJE's strategy built a bridge across local ideological divides for a single pacific mobilization largely participated by different stakeholders. Nevertheless, it is worth noticing that considerations of political opportunities made by these stakeholders and political actors had an impact on their disposal in joining the network. The shifts at the national level from the grievances between the Troika government and leftist groups and other civil society actors, to the establishment of the National Dialogue Quartet composed of UGTT, UTICA, the Tunisian Human Rights League and the Tunisian Order of Lawyers, had an impact on the political behaviour of local representatives of those organisations. UGTT and UTICA joined the ASSIDJEorganised cell as a result of alliances formed within the National Dialogue. In other words, political and ideological cleavages were still playing a role in local protests, and looking at the evolution of the network, it is clear how formal ideological cleavages still played a role in protest dynamics. 
In this context, the absence of a clear brand new collective identity allowing the 'crisis cell' network to overcome such inner divisions hindered network's survival. In the long run, and immediately after the strike, the lack of such a strategy created more tension than cohesion. In addition to the resilience of individual organisations' political agendas as source of mobilization, the ASSIDJE could not fully contain or replace their own source of legitimization, that in the eyes of many citizens was related to former authoritarian practices, a situation which had a detrimental impact on the sustainability of the network. Firstly, a few days before the general strike, the representative of the business association (UTICA) proposed a different date for the protest event, apparently for no reason, and ASSIDJE and the majority of its members refused to accommodate the switch, so the UTICA representative left the crisis cell. Subsequently, after the strike the representative of the workers union (UGTT) also left, stating that the crisis cell was no longer a representative, collective actor. ${ }^{20}$ Secondly, and as a consequence of this fragmentation, the remaining members of the crisis cell increasingly lost trust in the network and its ability to join together different actors for the sake of environmental issues. Some members, especially ordinary citizens, started to feel that the mobilisations were nothing but a political strategy on the part of the ASSIDJE and its president to emerge as a local political actor vis-à-vis the national transitional authorities, and that there was no real interest in setting a new, inclusive, style of bottom-up civic activism. Citizens began to feel that the crisis cell's organisational patterns represented a form of continuity with the authoritarian design of an opaque political space where information and strategies were closely held, and where different political actors played to their own interests.

With the lack of a new, clear identity around which to reinforce the mobilisation, the network built around the crisis cell could not maintain its momentum. Internally, the ASSIDJE's president, and aspiring leader of the network, sought to buttress the legitimacy of his own organization by arguing that the association had always maintained a leftist identity from the start since it criticised regime activities that affected the environment. Locally, as the ASSIDJE worked in collaboration with the Homt-Souk municipality before and after 2011 (and the municipality housed the association's offices for free), the president sought to avoid an open conflict with municipal authorities. As a result, the ASSIDJE did not specifically blame the Homt-Souk authorities for the garbage crisis, nor did it wish to target SEGOR, the private company that managed the landfill, but rather it targeted national institutions and their local branches. ${ }^{21}$ This position created tensions with a number of local activists who deemed the local council accountable for the garbage crisis. Nationally, the ASSIDJE's president strategically calculated that his association and its new extended network could exert influence on the Jomaa government's Minister of Environment; not least because he was a personal friend of the ASSIDJE's president, and he knew about the work and organizational capabilities of the association. ${ }^{22}$ However, in the eyes of many local members and activists, this strategy was seen as reinforcing the association's connections with distrusted former authoritarian institutions and as squandering an opportunity to strengthen new patterns of association and action between local actors. During an evening meeting of the crisis cell, some of the members appeared to be extremely dissatisfied with the soft position held by the ASSIDJE's leadership and stressed the need to organise more strikes and concrete actions against local authorities, including 
the governor, the local private society, and the need to organise awareness campaigns to involve citizens 'from the bottom'. 23

Eventually, notwithstanding the success of the general strike, the network's activities came to an end in late 2014 without ever delivering a consensual project to the national authorities. The network split up, and some of the various factions continued their activities independently.

Despite its limited successes in Djerba itself, the general strike organised by the ASSIDJE was instrumental in linking the local crisis and actors to larger environmental networks at the national level. Residents of Djerba living in the capital and other residents of Tunis organised a rally in solidarity with the island on Avenue Bourguiba, in front of the Ministry of Interior. During the rally, national institutions were blamed for the crisis, and the protesters mobilized against both Jomaa and Ennahda for their management of the rubbish crisis before 2014. On this occasion, SOS BIAA collaborated with the Djerba protesters and even organised a press conference on the issue. SOS BIAA brought together its network, made up the Association of Health Promotion (ATPS), and individual members such as engineers, scientists, students, and the activists from Tunis neighbourhoods who had already mobilized over the Borj Chekir issue. Moreover, on this occasion, and for the first time, the movement included a number of citizens from Djerba living in Tunis who wished to support the strike on the island from the capital. For this network, the Djerba crisis illustrated an important aspect of the environmental problems of the new Tunisia, problems that needed coordinated collective mobilization. SOS BIAA thus raised the profile of environmental issues in the media and highlighted the importance of collaborations among environmental activists. ${ }^{24}$

In the two cases presented here, the leadership of the networks (SOS BIAA and ASSIDJE) targeted the deterioration of the environmental situation in Tunisia by intelligently using structures and resources of mobilisation to organize their actions. Both groups sought to facilitate collective action by bypassing pre-existing personal political affiliations and avoiding any explicit political affiliation. This was a significant strategic choice in the immediate aftermath of the Tunisian revolution when ideological cleavages between national political actors repeatedly shaped protests on multiple issues as for or against the new regime. On one hand, the network around SOS BIAA started as an initiative by a single engineer to create an NGO to act as a 'watchdog' and to spread information about pollution. SOS BIAA's leader tried to establish new partnerships with associations and individual members from among those living in polluted areas, scientists and students with a clear interest in providing help with their expertise. In this case, technical expertise was the main source of identity for the network. On the other hand, the crisis cell network in Djerba originated from the initiative of a wellestablished local association and its leader, tying together different political actors as well as citizens, without establishing a specific identity (whether political, technical, or as a civil society organisation). This does not mean that the cases analysed in this paper, lacked mobilization along political lines in relation to environmental issues, but the cases do show that the leading actors did not primarily use political affiliations for network mobilisation. However, this strategy is not sufficient per se to guarantee the endurance of a network. The crisis cell created by ASSIDJE could not overcome the ideological, political and sectorial cleavages among its members for an extended period 
of time. The network split up without any organising any further mobilisations; part of the membership was persuaded that the crisis cell was a reproduction of older patterns of authoritarian control of local mobilisations, the disillusioned elements went back to their specific political agendas (as for the UGTT or the UTICA), or created new ones with specific goals and identities (see the next section).

The crisis cell's collective experience in Djerba was not especially transformative. The failure of the ASSIDJE leadership to present itself as an embodiment of new, more democratic practices with a new, clear identity during political instability, facilitated the reprioritization of a national agenda by several social and political actors previously in agreement within the crisis cell. Many members did not put aside their prior interests and affiliations for the sake of environmental mobilisation and participation in the network, and over time, in the face of various issues, citizens also increasingly lost interest.

SOS BIAA, by contrast, was more successful at bypassing these pre-existing affiliations by putting forward a more distinctive and distinct network identity. NGOs and individual members joined the network to support its advocacy campaign and the spreading of information about pollution and its implications for citizens' health. The NGOs and individuals joined because they could identify the rising of a network of environmental experts aiming at pressuring national authorities as well as international actors for improved access to information and changes in national legislation. The network connected technicians, citizens and associations around a clear agenda of serving as a 'watchdog' and the mobilisations targeted national institutions responsible for the management of water, earth and air pollution. By articulating an environmental agenda centring on the poor governance of solid waste management on a national level, SOS BIAA progressively buttressed its distinctive role in numerous cases around the country.

\section{The networks' evolution during the transition period}

The following section examines the outcome of the local mobilisations and highlights the role of the leaders' choices in relation to the formation of new group identities. In both Djerba and Tunis, each group tried to find its place in the local arena by articulating its grievances, in the first instance they targeted national institutions. The evolution of the two networks illustrates a redefinition of tactics centring on the interactions between local and national actors and arenas. Through this transformation of discourses and practices, the networks in this paper show how important local roots can be for activist organisations, and how their strong local connections and, in certain cases, longevity, can be vital assets, especially during a process of national political transition.

While ASSIDJE could not establish a new, distinctive identity and stable network around the experience of the crisis cell in Djerba, the crisis cell did serve as a hub for the formation and strengthening of connections and collaborations between activists. An interesting case is the Djerba, Authenticité, Patrimoine et Environnement (Djerba, Authenticity, Heritage and Environment (DAHE)). In this small association, the activists relied on personal ties and addressed the environmental crisis through smallerscale projects with a distinctive agenda. This grassroots network was founded by old acquaintances and college classmates who decided to pursue a service delivery agenda by reorganising local garbage collection in their respective neighbourhoods during the crisis. ${ }^{25}$ Albeit being part of it, they were sceptical about the ability of the crisis cell to 
improve the environmental situation on the island by pursuing objectives at national level during political instability. In their view, the most significant shortcoming of the cell was the inability of the ASSIDJE to create a wide consensus on its strategy and set an agenda for local activism after the general strike.

Rejecting the national authorities and public policy making in environmental matters as frame of mobilisation, they tried to deal with waste management shortcomings using local, context-based tactics and frame. Prioritizing practical solutions and efficiency, the DAHE network focused on the environmental problem from the perspective of public service provision. For example, they promoted the recycling of plastic bottles and then sold the plastic waste to the ANGeD's local agency. ${ }^{26}$ Some of the network's members were hotel directors with connections to local businessmen who supplied neighbourhoods and hotels with containers to which people could bring plastic bottles for recycling. This service delivery agenda brought together actors from different political backgrounds. Some of them were former RCD members, others were Ennadha and CPR supporters. The linkages between members were related to personal ties re-activated in the frame of environmental mobilisation, and many of them associated political parties with the top-down undemocratic control of local interests, inefficiency and corruption that could have hindered the delivery of services.

This local, embedded form of activism, based around specific and micro sources of pollution and a service delivery agenda, represented a new tactic on Djerba, one that reinforced an identity for this small association whose members progressively detached themselves from the crisis cell's meetings. This small group wished to mobilise local communities around a specific project, one of recycling and the spreading of good practices.

In fact, this re-scaling of goals to the local arena contributed to providing a new frame of mobilisation for networks and a reinforcement of their identity. This went in parallel with the institutional reorganization of the environmental networks in Tunis. The trend was indirectly fostered by the new Tunisian Constitution approved in January 2014 which promoted a new program of decentralisation that increased the number of municipalities and formally enlarged the prerogatives of elected local councils. International donors also played a role by supporting environmental initiatives that included a delocalisation of citizens participation and service provision. In this context, SOS BIAA expanded its network and started holding consultations with municipal authorities, as well as national institutions (Interior Ministry's Departments related to Local Authorities) in order to integrate its activities within the EU sponsored programmes such as the Programme d'Appui à la Société Civile (PASC). Since then, the association and its partner, the ATPS, have reinforced their international linkages while strengthening their role as mediators between citizens, public authorities and the private sector.

SOS BIAA relied on its new positioning as an environmental expert and mediator to renew its involvement in the crisis in Djerba in 2015. While SOS BIAA did not organise protests on the island, in March of that year it organised a conference. This event included many of the local actors that the crisis cell had brought together previously as well as the technical director of the private company that managed the island's landfill, Segor. The organizers produced a proposal that invited 'all stakeholders on the island to set aside their differences and work together to implement a common waste management strategy'. ${ }^{27}$ In this context they exploited their environmental expertise to put forward their role as environmental mediators, and deliver recommendations for a comprehensive action 
including public and private sector and civil society to evaluate and support implementation of selected projects for waste management on the island of Djerba.

The SOS BIAA network identity was thus consolidated around its two main roles: a watchdog identifying and denouncing waste management inefficiencies and pollution on a nation-wide basis, and a leading environmental association providing technical expertise to both local civil society organisations and businesses and institutions. The initial dynamics of the network built around the leaders' personal ties was progressively turned into a more institutionalized, associative structure and identity grounded on a formal expertise and agenda.

Both the SOS BIAA and DAHE networks took advantage of institutional instability and local activism to strengthen their durability. Both networks stressed the nonpolitical nature of their initiatives, as during the transitional phase, most citizens felt that political affiliation would have jeopardized any mobilization. Indeed, these groups identified their actions in the first instance with the technical and service oriented aspects of the environmental crisis. It is on this basis that, especially from 2015 onward, these networks built a dependable bridge between micro-scale activism and everyday local politics - one supporting technical activism tracking local health risks and supporting local institutions strengthening, the other framing actions within the local economy context of service delivery - and a broader agenda focusing on environmental protection at the national and even international level. These efforts were built upon strong personal ties, but at the same time they were accompanied by strong, new identity that could bind members together around specific goals. SOS BIAA strengthened the network by bringing together bureaucrats from national ministries, local activists, experts and scientists, and trying to expand to new local authorities at the local level. The DAHE association in Djerba represented an environmental mobilisation created by local actors, including business owners, who came from different political backgrounds. The (short to medium) durability of these networks was to some degree an outcome of the capacity of the leadership to outline a distinctive identity and set of practices that kept the legacy of authoritarian governance and its tendency toward political fragmentation and affiliation at arms' length.

\section{Conclusions}

This contribution analysed the specific dynamics found in environmental mobilisation and network formation during the Tunisian transition. The research helps to elucidate these networks strategies vis-à-vis different levels of state authorities, discourses about authority and expertise, and engagement with different stakeholders (including other networks) related to environmental issues. The work highlights the importance of different micro-strategies used by mobilising actors and leaders when organising contentious networks in the environmental domain during Tunisian transition. The analysis stresses which leaders' strategies create collective identities able to grant long-term survival to new emerging networks during political instability. The dynamics behind environmental networks' survival are particularly relevant to understand how the end of an authoritarian regime impact on mobilising strategies and how actors react to them. Their investigation sheds some light over the role of social ties in structuring enduring networks in a domain strongly controlled by undemocratic governance for 
many years. In this frame, further research on environmental networks dynamics and their distribution may improve the understanding of how mobilising opportunities evolve during transition and how networks are affected by political and institutional fragility in the longer run.

The analysis of the two environmental networks here presented stresses in the first instance the importance of, and the constraints imposed by, the authoritarian practices in place up until the 2011 uprisings. It illustrates how bypassing the patterns of mobilisation that were common under the old regime was an important step in order to bring together different social and political actors to address specific aspects of the environmental crisis that hit the country during this period. Although the new environmental networks that emerged at the time were built on strong personal social ties, and often included members of the old regime or institution, a principal factor of network durability was the formation of a new identity and agenda.

The networks' leaders sought to influence either local or national decisions by making their mark in the local political economies through personal social ties. In the cases analysed here, pre-existing personal ties were often at the root of successful networks. Leaders commonly used their personal resources in order to facilitate mobilisation, and the initial success of the networks was often tied to their personal connections and apparent apolitical character. However, gradual changes to the social ties that structure the relationships between the members emerged in all the cases, and it is in this sense that the role of leaders in moulding collective identity emerges in the case analysed. Those leaders' or members networks that introduced an innovative agenda as their identity marker (service delivery; watchdog supported by international donors; organisations raising awareness; partner for or with local authorities, etc.) succeed in position their networks between the citizens and the local administration, and/or between local and national actors for a longer term than those that neglect to build new collective identity as frame of mobilisation.

Those leaders who were not able to position the network clearly on the environmental map and also develop a distinct set of practices and capabilities exposed their networks to the disrupting forces of political and ideological competition, and to the return of authoritarian modes of participation. By contrast, those networks that were able to articulate a distinct environmentalist identity were able to take advantage of institutional instability. Such networks could expand and strengthen themselves by reaching out to the multiple localized protest mobilizations generated by the environmental crisis. The vacuum left by the collapse of local institutions and the process of rebuilding national institutions provided structural opportunities for local associations and citizens to mobilise without serious risks of repression. The transitional process and institutional instability enabled specific environmental entrepreneurs to promote their own agenda by creating personal social networks.

Ultimately, three dynamics for environmental networks unfolded during the specific transition period here considered. The first was that of a network with a short lifespan, such as the crisis cell in Djerba, which was able to rapidly mobilize and create consensus on a key local issue. The second was that of a sustainable network that was effective in local politics through the continuous involvement of local entrepreneurs and personalities on a defined set of localized environmental problems, as with Djerba, Authenticity, Heritage and Environment. The third and final dynamic was that of a 
network that went beyond the local level and interpersonal ties and promoted a specific environmentalist identity, agenda and strategy at the national level, as in the case of SOS BIAA.

\section{Notes}

1. The World Bank's initiatives included the three municipal development programmes introduced in Tunisia from 1992 to 2011 . Other local services targeted by these programmes included nursery schools, and the maintenance of roads, green areas and the sewage system; drinking water and sanitation services were provided on a national basis. Organic Law of Municipalities No. 75-33, Article 129 (14 May 1975), modified by Organic Law No. 95-68 (24 July 1995).

2. 'Deconcentration', typical of French administrative codes, 'involves the transfer of authority for specific decision-making, financial and management functions by administrative means to different levels under the same jurisdictional authority of the central government' (UNDP 1999, p. 7).

3. In order to be present in all municipalities, any party had to field about 4,000 candidates. In addition, in the legislative elections, the law provided for a $20 \%$ quota of seats reserved for opposition forces. However, in the 2000 municipal elections, the opposition lists had to obtain at least $3 \%$ in constituencies in which they had candidates in order to obtain the $20 \%$ of representatives on municipal councils (Gobe \& Chouikha, 2000, p. 11).

4. Interview with Abderraouf Mezzi, former mayor of Ettadhamen-Mnihila, October 2014, Ettadhamen, Ariana Governorate.

5. Interview with residents in el-Attar village, April 2014, el-Attar, Borj Chekir. Sources demanded anonymity.

6. Interview with worker at the Borj Chekir landfill and resident of the Sidi Hassine municipality. December 2013, Tunis. Source demanded anonymity.

7. Article 12 of the Municipal Organic Law no. 75-33 of 14 May 1975, modified by Municipal Organic Law no. 95-68 of 24 July 1995. When it was clear that municipal elections would not be organised in the short term, Constitutional Law 6/2011 of 16 December 2011 (called the 'petite constitution') removed the time limitation.

8. The National Commission of Inquiry into Corruption and Misappropriation (Commission Nationale d'Investigation sur les Affaires de Corruption et de Malversation), created in February 2011, focused on the outsourcing of the Borj Chekir dump. In July 2011, it highlighted that the French company Pizzorno had influenced the subcontracting agreements to its advantage. Nour El Houda Chaabane, 'La décharge de Borj Chakir: Corruption endémique et cadres institutionnels inadéquats.' Nawaat, 15 May 2015. https://nawaat.org/portail/2015/05/15/decharge-de-borj-chakir-corruption-cadreinstitutionnel-inadequat/ (accessed 24 November 2016).

9. Interview with Naceur Selmi, secretary of the UGTT division for municipal authorities, December 2013, Tunis.

10. Interview with Morched Garbouj, president of the NGO SOS BIAA, April 2014, Tunis.

11. Interview with residents in el-Attar village, April 2014, el-Attar, Borj Chekir. Sources demanded anonymity.

12. Interview with Karim Abdelwahed, April 2014, Tunis.

13. Participant observation of the 'Enjeux Environnementaux en Tunisie: La Gestion des Déchets et les Eaux Usées' Conference, 4 June, Tunis, 2014.

14. At that time, the three municipalities on the island were: municipality of Ajim, of HomtSouk and of Midoun.

15. In 2012 citizens organised sit-in and some people set the dump on fire, causing confrontations with the police. 'Guellala: Un désastre écologique à l'origine de violents affrontements entre les forces de l'ordre et les habitants.' Nawaat, October 2012. https://nawaat. 
org/portail/2012/10/06/tunisie-guellala-un-desastre-ecologique-a-lorigine-de-violentsaffrontements-entre-les-forces-de-lordre-et-les-habitants/ (Accessed 25 November 2016).

16. In Tunisia, the municipal staff is part of the national civil service. Administrative staff are hired through national competitions and appointed by the mayors under the direct control of governors.

17. Interview with Khaled M. and Marwen F. of the crisis cell, 22 October 2014, Homt-Souk, Djerba.

18. Interview with Naceur Bouabid, 21 October 2014, Homt-Souk, Djerba.

19. Participant observation of the crisis cell meeting held in October 2014, Homt-Souk, Djerba.

20. Interviews with activist of Front Populaire party, October 2014, Homt Souk, Djerba. Source demanded anonymity.

21. Interview with Naceur Bouabid, former president of the Association pour la Sauvegarde de l'île de Djerba, Djerba Homt-Souk, October 2014. See also Naceur Bouabid, 'Situation Catastrophique à Djerba.' Le Temps, 8 July 2014. http://www.letemps.com.tn/article/84548/ situation-catastrophique-\%C3\%A0-djerba. Accessed on 4 October 2017.

22. Interview with Naceur Bouabid, former president of the Association pour la Sauvegarde de l'île de Djerba, October 2014, Homt-Souk, Djerba.

23. Interview with crisis cell members, October 2014, Homt Souk, Djerba.

24. Participant observation of the press conference organised by SOS BIAA, 27 September, Bureau of the Press Union, Tunis.

25. Interview with members of the Djerba, Authenticité, Patrimoine et Environnement association. October 2014, Homt-Souk, Djerba.

26. Interview with Khaled M., member of the Djerba, Authenticité, Patrimoine et Environnement association, October 2014, Homt-Souk, Djerba.

27. Public announcement issued by SOS BIAA. Interview with Morched Garbouj, 10 January 2016, Tunis.

\section{Disclosure statement}

No potential conflict of interest was reported by the author.

\section{Notes on contributor}

Chiara Loschi is a postdoc at the Institute for European Integration Research, University of Vienna. She holds a PhD in Political Science and International Relations (University of Turin, Italy). She has conducted fieldwork in Libya in 2010 and for 5 years in Tunisia. In 2017, she has been CNRS postdoc at the French Institut de Recherche sur le Maghreb Contemporain (IRMC), in Tunisia, in the frame of an EU Horizon2020 project on EU crisis response in Libya, 'EUNPACK'.

\section{ORCID}

Chiara Loschi (D) http://orcid.org/0000-0002-7782-5583

\section{References}

Abu-Rish, Z. (2015). Garbage Politics. Merip 27, 45, “Iran’s Many Deals”. Retrieved from https:// www.merip.org/mer/mer277/garbage-politics

Alhamad, L. (2008). Formal and Informal Venues of Engagement. In E. Lust-Okar \& S. Zerhouni (Eds.), Political participation in middle east (pp. 3-47). Boulder, CO: Lynne Rienner. 
Allal, A., \& Bennafla, K. (2011). Les mouvements protestataires de Gafsa (Tunisie) et Sidi Ifni (Maroc) de 2005 à 2009. Des mobilisations en faveur du réengagement de l'État ou contre l'ordre politique? Revue Tiers Monde, 5, 27-45.

Antonakis-Nashif, A. (2016). Contested transformation: Mobilized publics in Tunisia between compliance and protest. Mediterranean Politics, 21(1), 128-149.

Ayeb, H. (2012). The marginalization of the small peasantry: Egypt and Tunisia. In R. Bush \& H. Ayeb (Eds.), Marginality and exclusion in Egypt (pp. 72-96). London: Zed Books.

Bayat, A. (1997). Street politics: Poor people's movements in Iran. New York: Columbia University Press.

Bayat, A. (2010). Life as politics. Stanford, CA: Stanford University Press.

Beinin, J., \& Vairel, F. (Eds.). (2011). Social movements, mobilization, and contestation in the Middle East and North Africa. Stanford: Stanford University Press.

Carpentier, I., \& Gana, A. (2017). Changing agricultural practices in the Oases of Southern Tunisia: Conflict and competition for resources in a post-revolutionary and globalisation context. In E. Lavie \& A. Marshall (Eds.), Oases and globalization. Ruptures and continuities (pp. 153-176). Cham: Springer.

Cirelli, C., \& Florin, B. (2015). Sociétés Urbaines et Déchets. Éclairages internationaux, Tours: PUFR.

Deboulet, A., \& Florin, B. (2014). Mobilisations pré-révolutionnaires: Quand les habitants des quartiers populaires du Caire (se) manifestent. Egypte-Monde Arabe, "Ville et révolution en Egypte". 11(1), 39-65.

Diani, M. (2003). Introduction: Social movements, contentious actions, and social networks: 'From metaphor to substance?'. In M. Diani \& D. McAdam (Eds.), Social movements and networks. Relational approaches to collective action (pp. 1-18). New York: Oxford University Press.

Diani, M., \& Mische, A. (2015). Network approaches and social movements. In D. Della Porta \& Diani (Eds.), The Oxford handbook of social movements (pp. 306-324). M. Oxford: Oxford University Press.

Feltrin, L. (2017). The struggles of precarious youth in Tunisia: The case of the Kerkennah movement, Review of African Political Economy,

Ferchichi, W. (2014). L'Environnement dans la Nouvelle Constitution Tunisienne du 27 Janvier 2014. Revue Juridique de l'Environnement, 39(2), 215-218.

Florin, B. (2012). Quand les chiffonniers du Caire osent! Mobilisations, contournements et résistances d'une communauté stigmatisée. In M. Lavergne (Ed.), Une société en quête d'avenir. Egypte, an 2 de la revolution (pp. 77-94)). Paris: L'Harmattan.

Fortier, E. A. (2015). Transition and Marginalization: Locating spaces for discursive contestation in post-revolution Tunisia. Mediterranean Politics, 20(2), 142-160.

Furniss, J. (2016). Postrevolutionary land encroachments in Cairo: Rhizomatic urban space making and the line of flight from illegality. Singapore Journal of Tropical Geography, 37(3), 310-329.

Geha, C. (Forthcoming). Politics of a garbage crisis: Social networks, narratives, and frames of Lebanon's 2015 protests and their aftermath. Social Movement Studies, 18, 1.

Gelvin, J. L. (2015). The Arab uprisings: What everyone needs to know. New York: Oxford University Press.

Gobe, E., \& Chouikha, L. (2000). Opposition et Élections en Tunisie. Monde Arabe MaghrebMachrek, 168, 29-40.

Gray, D. H. (2012). Tunisia after the uprising: Islamist and secular quests for women's rights. Mediterranean Politics, 17(3), 285-302.

Hibou, B. (2006). La Force de l'Obéissance. Economie Politique de la Répression en Tunisie. Paris: La Découverte.

Hoffmann, A., Bouziane, M., \& Harders, C. (2013). Analyzing politics beyond the center in an age of transformation. In M. Bouziane, A. Hoffmann, \& C. Harders (Eds.), Local politics and contemporary transformations in the Arab world. Governance beyond the center (pp. 1-21). London: Palgrave Macmillan. 
Huber, D., \& Lorenzo, K. (2015). Arab spring: The role of the peripheries. Mediterranean Politics, 20(2), 127-141.

Jasper, M. J. (2011). Introduction: From political opportunity structures to strategic interactions. In J. Goodwin \& J. M. Jasper (Eds.), Contention in context: Political opportunities and the emergence of protest (pp. 1-35). Stanford: Stanford University Press.

King, S. J. (2003). Liberalization against democracy. The local politics of economic reform in Tunisia. Bloomington: Indiana University Press.

Krinsky, J., \& Crossley, N. (2014). Social movements and social networks: Introduction. Social Movement Studies, 13(1), 1-21.

Leenders, R., \& Heydemann, S. (2012). Popular mobilization in Syria: Opportunity and threat, and the social networks of early risers. Mediterranean Politics, 17(2), 139-159.

McAdam, D., \& Paulsen, R. (1993). Specifying the relationship between social ties and activism. American Journal of Sociology, 99(3), 640-667.

Omri, M. (2013 September 23). Trade unions and the construction of a specifically Tunisian protest configuration. Open Democracy Blog. Retrieved from https://www.opendemocracy.net/ mohamed-salah-omri/trade-unions-and-construction-of-specifically-tunisian-protestconfiguration

Passy, F. (2003). Social networks matter. But how? In M. Diani \& D. McAdam (Eds.), Social movements and networks. Relational approaches to collective action (pp. 21-48). New York: Oxford University Press.

Polletta, F., \& Jasper, J. M. (2001). Collective identity and social movements. Annual Review of Sociology, 27, 283-305.

Preysing, D. (2016). Transitional Justice in post-revolutionary Tunisia (2011-2013): How the past shapes the future. Berlin: Springer.

Sadiki, L. (2002). Political liberalization in Bin Ali's Tunisia: Façade democracy. Democratization, 9(4), 122-141.

Signoles, P. (1999). Acteurs Publics et Acteurs Privés dans le Développement des Villes du Monde Arabe. In P. Signoles, G. E. Kadi, \& R. S. Boumedine (Eds.), L'Urbain dans le Monde Arabe: Politiques, Instruments et Acteurs (pp. 19-53). Paris: CNRS.

Singerman, D. (1995). Avenues of participation. Family, politics, and networks in Urban Quartiers of Cairo. Princeton studies in muslim politics. Princeton NJ: Princeton University Press.

Singerman, D. (2004). The networked worlds of Islamist social movements. In Q. Wiktorovicz (Ed.), Islamic activism: A social movement theory approach (pp. 143-163). Bloomington: Indiana University Press.

Sowers, J. (2013). Environmental politics in Egypt: Activists, experts and the state. Routledge studies in middle eastern politics. Taylor and Francis: New York, NY.

Tizaoui, H. (2009). Privatisation du Service de la Collecte des Ordures Ménagères en Tunisie. La 'Good Governance' ou la Mise à Niveau des Villes Tunisiennes, Étude de Cas: La Commune de Hamman el Chott. In J. M. Miossec (Ed.), Terrains et Échelons de la Gouvernance: Expériences en France et au Maghreb (pp. 231-265). Tunis-Paris: L'Harmattan.

UNPD. (1999). Decentralization. A sampling of definitions. Working Paper. Retrieved from http:// web.undp.org/evaluation/evaluations/documents/decentralization_working_report.PDF

Volpi, F. (2013). Explaining (and re-explaining) political change in the Middle East during the Arab Spring: Trajectories of democratization and of authoritarianism in the Maghreb. Democratization, 20(6), 969-990.

Volpi, F., Merone, F., \& Loschi, C. (2016). Local (R)evolutions in Tunisia, 2011-2014: Reconstructing municipal political authority. The Middle East Journal, 70(3), 365-381.

Wiktorovicz, Q. (2004). Islamic activism: A social movement theory approach. Bloomington: Indiana University Press.

Yahia, M. (2015). Taking out the trash: Lebanon's garbage politics. Carnegie Endowment for International Peace. Retrieved June 4th, 2018 from http://carnegie-mec.org/diwan/61102?lang=en 